\title{
Meningkatkan Minat Mengenal Konsep Bilangan Melalui Metode Bermain Alat Manipulatif
}

\author{
Adella Kharisma Diyenti \\ Universitas Negeri Padang \\ * e-mail: Adellakharima7@gmail.com
}

\begin{abstract}
Studying the concept of number is part of the learning procedure of counting. Learning to count is one lesson that had to be given to early childhood. However, learning to count in early childhood. Ability to know the concept of numbers can be done in various ways packaged in an interesting and innovative, so as to foster interest in learning and teaching children to know the concept can be conveyed to the maximum number. One way meninggkatkan child's ability in the concept of number is a manipulative play, manipulative play is a play that involves hand eye coordination and motor skills. Children need the opportunity to work on a delicate skill that involves little more control and direction. Playing the manipulative develop a sense of coordination, challenging their little finger to follow the line or use their tools properly. To increase interest in learning mathematics to children in kindergartens. This study was performed in group A in kindergarten IT Ar-Rahmah
\end{abstract}

Keywords: The concept of numbers, Play a Manipulative tool.

CC 1 Licensees may copy, distribute, display and perform the work an make derivative and remixes based on it only if they
give the author or licensor the credits (attributtion) in the manner specified by these. Licensees may copy, distribute,
display, and perform the work and make derivative works and remixes based on it only for non-commercial purposes

\section{PENDAHULUAN}

Manusia memiliki keistimewaan dibandingkan dengan binatang, yaitu manusia memiliki foresight yaitu kemampuan untuk menerawang dan mengantisipasi kehidupan masa depan terletak pada dari kondisi dan situasi hari ini, yaitu potensi kreatif yang sejak lahir dimilikinya. Dengan kata lain manusia tidak akan pernah berhenti untuk belajar menurut Bronwski dalam Rakimahwati (2012:1).

Belajar adalah suatu kebutuhan hidup bagi manusia untuk menjutkan kehidupannya baik itu yang bersumber dari dirinya sendiri dan juga sebagai makluk sosial ia harus mempertahankan hidupnya, dorongan yang tumbuh dari dlam diri manusia ini adalah dorongan untuk tumbuh dan berkembang serta dorongan untuk memepertahankan dirinya, dan selama hidupnya manusia tidak akan pernah berhenti belajar. Oleh karena itu Prayitno (2009:25) menjelaskan bahwa pendidikan merupakan wahana bagi pengembangan manusia. Pendidikan menjadi media bagi pemuliaan kemanusiaan yang tercermin dalam HMM dengan hakikat manusia, dimensi kemanusiaan, dan pancadayanya itu. Pendidikan ini dilaksanakan oleh manusia dan untuk manusia, serta hanya terjadi dlam hubungan antar manusia. 
Oleh karena itu sangat dibutuhkan pendidikan sejak dini, pendidikan anak usia dini adalah suatu upaya pembinaan yang ditujukan kepada anak sejak lahir samapai dengan usia enam tahun, dilakukan melalui pemberian ransangan pendidikan untuk membantu pertumbuhan dan perkembangan jasmani agar anak memiliki kesiapan dalam memasuki pendidikan lebih lanjut. ( UU No.20 tahun 2003).

Penyelenggaraan pendidikan PAUD menititik beratkan pada pondasi dasar ke arah pertumbuhan dan perkembangan fisik, kecerdasan, sosial emosional, bahasa, dan komunikasi, sesuai dengan keunikan dan tahap-tahap yang akan dilalui oleh anak usia dini, karana secra umum PAUD bertujuan untuk mengembangkan berbagai potensi anak sejak dini sebagai persiapan untuk hidup dan menyesuaikan diri dengan lingkungannya, pada masa itu nilai-nilai positif yang ditanamkan kepada mereka akan mejadi modal dasar untuk perekmbangan selanjutnya.

Anak dalam beragam usia dengan berbagai perilakunya biasanya menarik perhatian orang dewasa. Dunia anak adalah dunia yang penuh dengan canda tawa dan kegembiraan sehingga orang dewasa akan ikut terhibur dengan tingkah polah mereka. Pada kehidupan sehari-hari, berbagai tingkat usia anak dapat kita amati. Ada bayi, balita,anak usia TK sampai anak usia Sekolah Dasar. Semua kategori umur tersebut dikelompokkan sebagai fase anak usia dini (Aisyah, 2007- modul 1) dalam Nonike Rose Sodikin

Anak usia dini mengalami pertumbuhan dan perkembangan sangat pesat. Oleh karena itu usia dini sering disebut dengan istilah golden age atau masa keemasan yang pada hakikatnya masa usia dini dalah masa peletak dasar awal pertumbuhan dan perkembangan selanjutnya. Untuk mengetahui kosenp matemaika, sains, dan ilmu lainnya guru harus mengetahui cara berfikir anak, menurut Piaget (1972) dalam strategi pendidikan anak Slamet Yusanto perekembangan kognitif anak usia 5-6 tahun beralih dari fase praoperasional ke fase konkret operasional. Cara berfikir konkret berpijak pada pengalaman akan benda-benda konkret bukan berdasarkan pengetahuan atau konsep-konsep abstrak.

Menurut Sujiono (2009:7), Anak usia dini merupakan usia penting bagi perkembangan kognitif anak yang mampu menyerap informasi secara cepat. Pentingnya pendidikan dalam mengembangkan kognitif anak yaitu agar anak mampu mengembangkan daya pikir termasuk dalam mengenal konsep bilangan. Konsep bilangan adalah ide atau rancangan pengetahuan dalam memahami kumpulan angka-angka dan menanyakan nilai banyak anggota suatu benda dalam matematika (Inra, 2012:371) dalam Nonike Rose Sodikin

Menurutu Caufield (dalam Wasik \& seefeldt 2008:393), mempelajari konsep bilangan merupakan bagian dari belajar tata cara berhitung. Belajar berhitung merupakan salah satu pelajaran yang memang harus diberikan kepada anak usia dini. Akan tetapi belajar berhitung pada anak usia dini berbeda dengan pembelajaran di sekolah dasar misalnya pada anak usia dini belajar 
mengenal bilangan melalui kegiatan menghitung jumlah balok yang digunakan untuk bermain, membaca jam dan lain sebagainya. Kemampuan mengenal konsep bilangan dapat dilakukan dengan berbagai cara yang dikemas secara menarik dan inovatif, sehingga dapat menumbuhkan minat belajar anak dan pembelajaran mengenal konsep bilangan dapat tersampaikan secara maksimal.

Berdasarkan hasil observasi di TK IT Ar-Rahmah Kec. Nanggalo kemampun pada anak kelompok A untuk mengenal konsep bilangan 1-10 masih rendah dalam hal membilang, menunjuk, dan membuat urutan bilangan 1-10. Kebanyakan dari mereka sudah belajar tentang nama-nama bilangan namun belum mampu menilai lambang-lambangnya khususunya pada bilangan 1-10. Sementara sesuai dengan Peraturan Menteri Pendidikan Nasional No 58 Tahun 2009 untuk tingkat pencapaian perkembangan aspek konsep bilangan idealnya mampu mengenal konsep bilangan 1 sampai 10 dengan benar dan mandiri

Berdasarkan latar belakang permasalahan tersebut peneliti berinisiatif melakukan penelitian dengan judul "Meningkatkan Minat Mengenal Konsep Bilangan Melalui Metode Bermain Alat Manipulatif Pada Anak Kelompok A di TKIT Ar-Rahmah” Berdasarkan latar belakang di atas, maka dapat dirumuskan tujuan penelitian sebagai berikut : (1) meningkatkan minat anak dalam belajar matematika melalui metode bermain alat manipulatif, (2) mengetahui proses kegiatan belajar menggunakan metode bermain alat manipulatif dalam meningkatkan minat mengenal konsep bilangan pada anak kelompok A di TK IT Ar-Rahmah.

\section{PEMBAHASAN}

\section{A. Konsep Bilangan}

Potensi-potensi yang dimiliki setiap anak yang dapat dikembangkan meliputi perkembangan nilai agama dan moral, fisik motorik, kognitif, bahasa serta sosial emosional. Kemampuan kognitif merupakan salah satu dari kemampuankemampuan yang harus dicapai dalam pembelajaran anak usiadini. Seperti halnya yang telah dikemukakan oleh Piaget yang membagi empat tahap perkembangan kognitif anak usia dini dan salah satunya pada tahap pra operasional. Pada tahap ini anak mempelajari masalah sebelum bertindak dan terlibat dalam kegiatan trial and error secara fisik. Anak dapat menggunakan simbol dan pikiran internal dalam memecahkan masalah, pikiran mereka masih terkait dengan objek konkret saat ini dan sekarang (Fridani, L., Wulan, S., \& Pujiastuti S.I . 2008:3.8).

Pengembangan kemampuan matematika berarti mempersiapkan anak menjadi individu yang memiliki kemampuan untuk berfungsi sebagai pemecah masalah karena dalam melakukan kegiatan matematika, anak dapat menerapkan berbagai strategi matematika dan menemukan jawaban dari masalah yang dihadapinya (Jamaris, 2014: 181). 
Pengembangan di Taman kanak-kanak dapat dilihat dari kemampuan dasar berhitung yaitu kemampuan melihat, membedakan, meramalkan, memisahkan, dan mengenal konsep angka, selain itu berhitung mampu meningkatkan kemampuan anak dalam memecahkan masalah, serta kemampuan, mengukur/ memperkirakan mengetahui serta membedakan konsep ruang. Penelitian yang dilakukan oleh Widawati (2010 : 74-75) di Taman Kanak-Kanak Kenanga membuktikan bahwa penggunaan media pembelajaran yang diangkat dari pengalaman sehari-hari anak dapat membantu pemahaman anak terhadap konsep matematika khususnya berhitung. Melalui pendekatan matematika realistik, berhitung bagi anak bukan hanya menghitung deret angka saja, melainkan sebuah proses yang lebih bermakna dan menyenangkan Sedangan penelitian yang dilakukan oleh Andari, (2008:120-122)

Howard Gardner sebagaimana dikutip Munif Chatib menyebutkan bahwa kecerdasan logika matematika adalah kepekaan pada memahami pola-pola logis atau numeris dan kemampuan mengolah alur pemikiran yang panjang (Munif Chatib, 2011:56). Kecerdasan logika matematika berkaitan erat dengan kemampuan berhitung, menalar, dan berfikir logis, serta memecahkan masalah. Dengan kata lain, seorang anak yang mempunyai kecerdasan logika matematika secara dominan akan lebih menyukai dunia hitung menghitung dan mengedepankan logika dalam menyelesaian persolan.

Jadi dapat dipahami bahwa seseorang yang mempunyai kecerdasan logika matematika akan lebih memiliki kemampuan dalam hal perhitungan dan berfikir secara logis. Dengan mengajarkan anak-anak kemampuan logika matematika akan dapat melatih anak untuk mengenal perhitungan dan melakukan penalaran dalam setiap menghadapi suatu masalah. Selain itu juga, ada beberapa nilai-nilai yang patut ditanamkan kepada anak-anak, agar mereka menjadi pribadi berkarakter,yakni: 1) cinta Tuhan dan segenap ciptaanNya; 2) tanggung jawab, kedisiplinan dan kemandirian; 3) kejujuran/amanah dan arif; 4) hormat dan santun; 5) dermawan, suka menolong dan gotongroyong/ kerjasama; 6) percaya diri, kreatif dan pekerja keras; 7) kepemimpinan dan keadilan; 8) baik dan rendah hati; 9) toleransi, kedamaian dan kesatuan (Megawangi, 2004:2). Nilai-nilai tersebut sangat tepat digunakan sebagai pembentukan dasar kepribadian, pengembangan, dan pembentukan kepribadian anak. Proses pembelajaran dengan memberikan rangsangan belajar bagi anak sesuai dengan kecerdasan yang dimiliki anak akan sangat menentukan masa depan.

Menurut Harjanto (2011: 17), "Banyak manfaat yang didapat oleh anak dengan mengenal bilangan. Ia menjadi akrab dengan angka yang akan ditemui di sepanjang kehidupannya sekaligus melatih daya ingatnya". Pada prinsipnya kemampuan mengenal konsep bilangan anak usia dini dapat ditingkatkan asalkan guru mengetahui cara yang tepat. Sesuai dengan Peraturan Menteri 
Pendidikan Nasional (Permendiknas ) No 58 tahun 2009 dalam mengontrol pembelajaran anak usia 4-6 tahun, penerapan pembelajaran pendidikan di TK tidak diperkenankan mengajarkan materi calistung secara langsung. Sehingga perlu media untuk mengenalkan pembelajaran tersebut. Penggunaan alat peraga yang menarik perhatian dan dapat meningkatkan minat dan motivasi anak untuk belajar.

Menurut Caufield (dalam Wasik \& seefeldt 2008:393), mempelajari konsep bilangan merupakan bagian dari belajar tata cara berhitung. Belajar berhitung merupakan salah satu pelajaran yang memang harus diberikan kepada anak usia dini. Akan tetapi belajar berhitung pada anak usia dini berbeda dengan pembelajaran di sekolah dasar misalnya pada anak usia dini belajar mengenal bilangan melalui kegiatan menghitung jumlah balok yang digunakan untuk bermain, membaca jam dan lain sebagainya. Kemampuan mengenal konsep bilangan dapat dilakukan dengan berbagai cara yang dikemas secara menarik dan inovatif, sehingga dapat menumbuhkan minat belajar anak dan pembelajaran mengenal konsep bilangan dapat tersampaikan secara maksimal.

Permainan konsep bilangan merupakan bagian dari matematika, diperlukan untuk menumbuh kembangkan keterampilan berhitung yang sangat diperlukan dalam kehidupan seharihari, terutama konsep bilangan yang merupakan juga dasar bagi pengembangan kemampuan matematika maupun kesiapan untuk mengikuti pendidikan dasar.

Pentingnya mengenal konsep bilangan pada anak usia dini yaitu dapat mengembangkan segenap potensi yang ada pada diri anak, salah satunya dapat belajar mengenal urutan bilangan dan pemahaman konsep bilangan dengan baik sehingga dapat diterapkan dalam kehidupan seharihari melalui kegiatan menghitung benda-benda yang ada di sekitar anak. Adapun tujuan mengenal konsep bilangan yaitu agar anak dapat berpikir logis dan sistematis sejak dini melalui pengamatan terhadap benda-benda konkret di sekitar anak sehingga anak lebih siap untuk mengikuti jenjang pendidikan selanjutnya ( Depdiknas, 2007:2) dalam Widya Ismaulinda Nur Azizah.

Apabila anak diberikan sejak dini berhitung akan mampu merangsang anak dalam memahami fenomena alam atau perubahan lingkungan disekitarnya. Kemampuan ini akan diperoleh anak secara alamiah dan berlangsung selama bertahun-tahun seiring dengan bertambahnya usia. Proses perkembangan ini merupakan salah satu tahapan tentang dalam proses perkembangan intelektual anak.

\section{B. Hakekat Bermain}

Manusia bermain sepanjang rentang kehidupannya dalam setiap kebudayaan yang ada di dunia. Anak usia Taman kanak-kanak sebagai bagian anak kelompok usia dini identik dengan usia bermain, oleh karena itu pembelajaran harus memperhatikan kesesuaian dengan usianya. Dengan kata lain pembelajaran harus dilakukan dengan melalui kegiatan bermain. Banyak para 
ahli pendidik PAUD yang menyatakan bahwa bermain sebagai kegiatan yang dapat dimanfaatkan untuk menstimulasi pertumbuhan dan perkembangan anak.

Vygotstky dalam Slamet Suyanto (2003:136) menyatakan bahwa pada saat bermain pikiran anak terbebas dari situasi kehidupan yang nyata yang menghambat anak berpikir abstrak. Selain itu bermain juga dapat mengembangkan kemampuan afektif anak, karena dalam bermain terdapat aturan bermain yang mampu merangsang anak akan pentingnya peraturan untuk dipatuhi. Tidak hanya itu perkembangan bahasa dan social emosional serta fisik anak juga dapat berkembang dengan pesat pada saat kegiatan bermain.

Menurut Vygotky dalam slamet suyanto (2003:137) pada saat anak melakukan percakapan maka anak sedang dalam tahap menggabungkan pikiran dan bahasa sebagai satu kesatuan. Pada saat melakukan interaksi dengan teman saat bermain ini pula maka anak akan belajar bagaimana merespon, memberi, menolak atau setuju ide dan perilaku anak yang lain. Menurut Mayesty (dalam yuliani NS,2009:144) bermain adalah kegiatan yang anak-anak lakukan sepanjang hari karena bagi anak bermain adalah hidup dan hidup adalah permainan. Menurut Hurlock,1997 (dalam Tadkiroatun Musfiroh,2008 : 1) bermain adalah kegiatan yang dilakukan atas dasar suatu kesenangan dan tanpa mempertimbangkan hasil akhir, kegiatan tersebut dilakukan secara suka rela,tanpa paksaan,atau tekanan dari pihak luar.

Piaget dalam Yuliani (2009:144) mengatakan bahwa bermain adalah suatu kegiatan yang dilakukan berulang - ulang dan menimbulkan kesenangan atau kepuasan bagi diri seseorang. Dari beberapa pernyataan tersebut diatas tentang bermain dapat diambil kesimpulan bahwa bermain adalah suatu kegiatan yang dilakukan anak atas dasar kesenangan dan atas dasar rasa ingin dan bukan karena harus memenuhi tujuan atau keinginan orang lain.

Karakteristik bermain pada anak usia dini yang perlu dipahami oleh stimulator menurut Jeffree,McConkeydan Hewson dalam Yuliani N.S (2009:146-147) yaitu :

a. Bermain muncul dari dalam diri anak

Keinginan bermain harus muncul dalam diri anak, sehingga anak dapat menikmati dan bermain sesuai dengan caranya sendiri, itu artinya bermain dilakukan dengan suka rela tanpa paksaan.

b. Bermain harus bebas dari aturan yang mengikat, kegiatan untuk di nikmati.

Bermain pada anak usia dini harus terbebas dari aturan yang mengikat, karena anak usia dini memiliki cara bermainnya sendiri. Untuk itulah bermain pada anak selalumenyenangkan,mengasikkan dan menggairahkan. 
c. Bermain adalah aktivitas nyata atau sesungguhnya.

Dalam bermain anak melakukan aktivitas nyata, misalnya pada saat anak bermain dengan air,anak melakukan aktivitas dengan air dan mengenal air dari bermainnya. Bermain melibatkan partisipasi aktif baik secara fisik maupun mental.

d. Bermain harus difokuskan proses dari pada hasil

Dalam bermain anak harus difokuskan pada proses bukan hasil yang diciptakan anak. Dalam bermain anak mengetahui apa yang dia mainkan dan mendapatkan ketrampilan baru,mengembangkan perkembangan anak dan anak memperoleh pengetahuan dari apa yang dia mainkan.

e. Bermain harus didominasi oleh pemain

Dalam bermain harus di dominasi oleh pemain,yaitu anak itu sendiri tidak di dominasi oleh orang dewasa,karena jika didominasi oleh orang dewasa maka anak tidak akan mendapatkan makna apapun dari bermainnya.

f. Bermain harus melibatkan peran aktif dari pemain.

Anak sebagai pemain harus terjun langsung dalam bermain. Jika anak pasif dalam bermain tidak akan mendapatkan pengalaman baru, karena bagi anak bermain adalah bekerja untuk mendapatkan pengetahuan dan ketrampilan baru

\section{Manfaat bermain :}

Beberapa manfaat yang bisa diperoleh seorang anak melalui bermain antara lain (Zaviera, 2008):

a. Aspek fisik, dengan mendapat kesempatan untuk melakukan kegiatan yang banyak melibatkan gerakan - gerakan tubuh, akan membuat tubuh anak menjadi sehat.

b. Aspek perkembangan motor kasar dan halus, hal ini untuk meningkatkan ketrampilan anak.

c. Aspek sosial, anak belajar berpisah dengan ibu dan pengasuh. Anak belajar menjalin hubungan dengan teman sebaya, belajar berbagi hak, mempertahankan hubungan, perkembangan bahasa, dan bermain peran sosial.

d. Aspek bahasa, anak akan memperoleh kesempatan yang luas untuk berani bicara. Hal ini penting bagi kemampuan anak dalam berkomunikasi dan memperluas pergaulannya.

e. Aspek emosi dan kepribadian. Melalui bermain, anak dapat melepaskan ketegangan yang dialaminya. Dengan bermain berkelompok, anak akan mempunyai penilaian terhadap dirinya tentang kelebihan yang dimiliki sehingga dapat membantu perbentukan konsep diri yang positif, mempunyai rasa percaya diri dan harga diri.

f. Aspek kognisi. Pengetahuan yang didapat akan bertambah luas dan daya nalar

g. juga bertambah luas, dengan mempunyai kreativitas, kemampuan berbahasa, 
h. dan peningkatan daya ingat anak.

i. Aspek ketajaman panca indra. Dengan bermain, anak dapat lebih peka pada hal- hal yang berlangsung dilingkungan sekitarnya.

j. Aspek perkembangan kreativitas. kegiatan ini menyangkut kemampuan melihat sebanyak mungkin alternatif jawaban. Kemampuan divergen ini yang mendasari kemampuan kreativitas seseorang.

k. Terapi. Melalui kegiatan bermain anak dapat mengubah emosi negatife menjadi

1. positif dan lebih menyenangkan.

\section{Bermain Manipulatif}

Bermain manipulatif adalah Bermain yang melibatkan koordinasi tangan mata dan keterampilan motorik. Anak-anak membutuhkan kesempatan untuk bekerja pada keterampilan halus yang melibatkan sedikit kontrol lebih dan arah. Bermain manipulatif mengembangkan rasa koordinasi, menantang jari kecil mereka mengikuti garis atau menggunakan alat-alat mereka benar. Untuk meningkatkan minat pembelajaran matematika kepada anak TK, peneliti memilih metode bermain alat manipulatif karena aktivitas bermain merupakan aktivitas dominan yang menyenangkan bagi mereka.

Dengan mengutip pendapat Gerlach \& Ely, I Wayan Santyasa (2001:4) menyebutkan tiga kelebihan kemampuan media. Pertama, kemampuan fiksatif, artinya dapat menangkap, menyimpan, dan menampilkan kembali suatu obyek atau kejadian. Dengan kemampuan ini, obyek atau kejadian dapat digambar, dipotret, direkam, difilmkan, kemudian dapat disimpan dan pada saat diperlukan dapat ditunjukkan dan diamati kembali seperti kejadian aslinya. Kedua, kemampuan manipulatif, artinya media dapat menampilkan kembali obyek atau kejadian dengan berbagai macam perubahan (manipulasi) sesuai keperluan, misalnya diubah ukurannya, kecepatannya, warnanya, serta dapat pula diulangulang penyajiannya. Ketiga, kemampuan distributif, artinya media mampu menjangkau audiens yang besar jumlahnya dalam satu kali penyajian secara serempak, misalnya siaran TV atau Radio.

Media manipulatif dalam pembelajaran matematika adalah alat bantu pembelajaran yang digunakan terutama untuk menjelaskan konsep dan prosedur matematika. Media ini merupakan bagian langsung dari mata pelajaran matematika dan dimanipulasikan oleh anak (dibalik, dipotong, digeser, dipindahkan, digambar, dipilah, dikelompokkan atau diklasifikasikan (Muhsetyo, G, 2009: 2.31). Hal tersebut sependapat dengan Domino (2010: 2), media manipulatif menurut Kennedy didefinisikan sebagai, "objects that appeal to several senses and that can be touched, moved about, rearranged, and otherwise handled by children". Hartshorn dan Boren 
menambahkan, media manipulative mengacu benda-benda yang dapat disentuh dan digerakkan oleh anak untuk memperkenalkan atau memperkuat konsep matematika. Sehubungan dengan itu Clements mendefinisikan media manipulatif yang baik adalah yang dapat membantu anak dalam membangun, memperkuat, dan menghubungkan berbagai representasi dari ide-ide matematika. Media manipulatif adalah semua alat permainan yang kecil dan dapat diletakkan di atas meja sehingga membuat anak terampil bekerja dan mengembangkan daya pikirnya (Sudono, 2000: 128129)

Dari beberapa pendapat diatas dapat disimpulkan bahwa bermain manipulatif adalah bermain yang melibatkan koordinasi tangan mata dan keterampilan motorik. Anak-anak membutuhkan kesempatan untuk bekerja pada keterampilan halus yang melibatkan sedikit kontrol lebih dan arah. Bermain manipulatif mengembangkan rasa koordinasi, menantang jari kecil mereka mengikuti garis atau menggunakan alat-alat mereka benar. Untuk meningkatkan minat pembelajaran matematika kepada anak TK, peneliti memilih metode bermain alat manipulatif karena aktivitas bermain merupakan aktivitas dominan yang menyenangkan bagi mereka.

\section{PENUTUP}

Pendidikan anak usia dini adalah suatu upaya pembinaan yang ditujukan kepada anak sejak lahir samapai dengan usia enam tahun, dilakukan melalui pemberian ransangan pendidikan untuk membantu pertumbuhan dan perkembangan jasmani agar anak memiliki kesiapan dalam memasuki pendidikan lebih lanjut. Dengan mengajarkan anak-anak kemampuan logika matematika akan dapat melatih anak untuk mengenal perhitungan dan melakukan penalaran dalam setiap menghadapi suatu masalah. Selain itu juga, ada beberapa nilai-nilai yang patut ditanamkan kepada anak-anak, agar mereka menjadi pribadi berkarakter,yakni: 1) cinta Tuhan dan segenap ciptaanNya; 2) tanggung jawab, kedisiplinan dan kemandirian; 3) kejujuran/amanah dan arif; 4) hormat dan santun; 5) dermawan, suka menolong dan gotongroyong/ kerjasama; 6) percaya diri, kreatif dan pekerja keras; 7) kepemimpinan dan keadilan; 8) baik dan rendah hati; 9) toleransi, kedamaian dan kesatuan. Untuk itu sasah satu permainan yang bisa meninggkatkan kemampuan ank dalam mengenal matematika adalah dengan bermain manipulatif karena permainan ini merupakan salah satu hal yang menyenagkan untuk anak usia dini

\section{Daftar Pustaka}

Apriliana Cahyaningrum, Meningkatkan Kemampuan Berhitung Melalui Media Balok Pada Anak Kelompok B Tk Guworejo 2 Karang Malang Kabupaten Sragen

(Meningkatkan Minat Mengenal Konsep...) 
Apriyana Cahyaningrum, Peningkatan Kemampuan Mengenal Konsep Bilangan Melalui Penggunaan Media Manipulatif Pada Kelompok B TK Aisyiyah Bustanul Athfal Karangasem Tahun Ajaran 2014/2015

Mudji Astuti, Penggunaan Metode Bermain Alat Manipulatif Dalam Meningkatkan Minat Mengenal Konsep Bilangan Pada Siswa Kelompok B Tk Islam Ar Ridlo Tahun Pelajaran 2013/2014, diakses pada 18 Desember 2017

Nonike Rose Sodikin Pengaruh Permainan Bowling Modifikasi Terhadap Kemampuan Mengenal Konsep Bilangan Anak Kelompok A Tk Pgri Desa Prunggahan Kulon Kecamatan Semanding Kabupaten Tuban, diakses pada 18 Desember 2017

Rakimahwati, 2012, Model Pembelajaran Sambil Bermain Pada Anak Usia Dini, padang : UNP Press,

Suyanto, Slamet, 2008, Strategi Pendidikan Anak (Pengenalan Dengan Matematika, Sains, Seni, Bahasa Dan Pengetahuan Sosial, Yogyakarta: Hikayat Publising

Widya Ismaulinda Nur Azizah / Dra. Wiwik Widajati, M. Pd. Pengaruh Metode Proyek Terhadap Kemampuan Pengenalan Konsep Bilangan Pada Anak Kelompok A Di Tk Taruna Bhakti Tambaksari Surabaya 